\title{
Chapter 11 \\ Recovering the Gay Village: \\ A Comparative Historical Geography \\ of Urban Change and Planning \\ in Toronto and Sydney
}

\section{Andrew Gorman-Murray and Catherine J. Nash}

\begin{abstract}
This chapter argues that the historical geographies of Toronto's Church and Wellesley Street district and Sydney's Oxford Street gay villages are important in understanding ongoing contemporary transformations in both locations. LGBT and queer communities as well as mainstream interests argue that these gay villages are in some form of "decline" for various social, political, and economic reasons. Given their similar histories and geographies, our analysis considers how these historical geographies have both enabled and constrained how the respective gay villages respond to these challenges, opening up and closing down particular possibilities for alternative (and relational) geographies. While there are a number of ways to consider these historical geographies, we focus on three factors for analysis: postWorld War II planning policies, the emergence of "city of neighborhoods" discourses, and the positioning of gay villages within neoliberal processes of commodification and consumerism. We conclude that these distinctive historical geographies offer a cogent set of understandings by providing suggestive explanations for how Toronto's and Sydney's gendered and sexual landscapes are being reorganized in distinctive ways, and offer some wider implications for urban planning and policy.
\end{abstract}

Keywords Toronto, Canada $\cdot$ Sydney, Austrlia $\cdot$ Neighborhood $\cdot$ Gayborhood $\cdot$ Urban Change $\cdot$ Urban Planning

\subsection{Introduction}

In this chapter, we examine the historical geographies of the now iconic gay villages in Toronto's Church and Wellesley Street district and Sydney's Oxford Street. We argue that a comparative historical geography approach provides insights into complex

\author{
A. Gorman-Murray $(\bowtie)$ \\ School of Social Sciences, Western Sydney University, Sydney, NSW, Australia \\ e-mail: a.gorman-murray@westernsydney.edu.au \\ C. J. Nash \\ Geography and Tourism Studies, Brock University, St. Catharines, ON, Canada \\ e-mail: cnash@brocku.ca
}


and multidimensional processes fomenting an ongoing and distinctive reordering of gendered and sexual landscapes occurring in both Toronto and Sydney. In doing so, we contribute to the ongoing debates about the nature, characteristics, and implications of the shifting fortunes of some traditional gay villages in the Global North.

We begin by discussing geographical scholarship on the emergence of gay villages in the Global North with an emphasis on contemporary literature detailing the perceived "decline" of some longstanding gay villages, including those in Toronto and Sydney. We also explain why a comparative historical geography of Toronto and Sydney is insightful. We then present the distinctive historical geographies underpinning the emergence of each city's gay neighborhoods in the post-World War II period, discussing convergences and divergences. The concluding discussion underscores the differences and draws on our historical geographical analysis to pose questions about their future. Throughout, the acronym LGBT (lesbian, gay, bisexual, trans) refers to identities grouped together to reflect collective interests and community as gendered and sexual minorities, while queer denotes a contemporary moment when some individuals reject a gendered and sexual specificity but still position themselves within non-normative gender and sexual understandings-a positioning reflected in recent urban changes.

\subsection{Historical Geographies of Gay Villages: Segregation and Integration}

A substantial body of scholarship examines the emergence and development of gay villages in the Global North in the period following World War II. This research highlights the dominant role that gay men (mainly white and middle-class) played in the development and growth of gay villages, initially through their appropriation of places for safety and support to their use of these neighborhoods for political, social, and economic security and activism (Castells 1983; Chauncey 1994; Doan and Higgins 2011; Gorman-Murray and Waitt 2009; Knopp 1990; Lewis 2012; Nash 2006). Simultaneously, lesbians and queer women also inhabited urban locations and neighborhoods and utilized gay village spaces, albeit in distinctive and less visible ways (Adler and Brenner 1992; Nast 2002; Podmore 2001, 2013; Rothenberg 1995; Valentine 1993, 1996). Throughout the 1960s and 1970s, these districts increasingly engaged in local politics, consolidating their presence and creating community through economic development, the provision of services, and political activism around rights protections. The HIV/AIDS crisis of the 1980s helped cement villages as hubs of LGBT life, and in places such as Toronto and Sydney they provided core services including hospice care, outreach, health education, and counseling services (Kinsman 1996; Warner 2002; Willett 2000a; Wotherspoon 1991).

In the 1980s, gay villages were increasingly caught up in broader urban social and economic processes that saw them incorporated, through the neoliberal policy 
initiatives of the entrepreneurial city, into increasingly commodified and consumable urban landscapes (Bell and Binnie 2002; Binnie 2000; Binnie and Skeggs 2004; Visser 2008). Currently, both Toronto and Sydney represent their respective villages as examples of their tolerance and openness to diversity. This incorporation into mainstream urban life has prompted some scholars to argue that the assimilation of some LGBT people into mainstream life both reflects and reinforces LGBT "neoliberal sexual politics" that privilege those gendered and sexual minorities who are willing to participate in normative, middle-class, consumer society within monogamous married coupledom (Brown 2008; Duggan 2003; Richardson 2005). This framing of a "homonormative politic" has prompted some to argue that we cannot understand this to be a universal or monolithic result and that we need to attend to the "difference, unevenness and geographical specificity" of gendered and sexual relations in the gay village and beyond (Brown 2009: 1498).

As recent scholarship suggests, contemporary gay villages, including those in Toronto and Sydney, are experiencing forms of "degaying" within broader political, social, and economic processes at work in many Global North cities (Collins 2004; Ruting 2008; Gorman-Murray and Waitt 2009; Nash 2013a; Visser 2013). Part of this process is the commodification of gay villages as tourist venues, as well as shopping and entertainment districts, which has attracted a wide variety of consumers and businesses not necessarily identifying as LGBT. Many LGBT venues are now popular with heterosexuals while other social spaces such as bars and restaurants are becoming more mixed or have lost their queer sensibility entirely. In both Canada and Australia, legislative and social recognition of LGBT people has resulted in their increasing visibility in a broad range of locations beyond the gay village in places understood to be "gay friendly." While many argue this new visibility is only available to certain normatively gendered and sexualized gays and lesbians, others suggest these spatial changes reflect greater acceptance of sexual and gendered difference, as well as a growing social cohesion across a wide variety of neighborhoods (Ghaziani 2021; Gorman-Murray and Waitt 2009; Nash 2013a; Visser 2013). Nevertheless, as scholars argue, while some gays and lesbians are able to fully integrate into the mainstream, others continue to be marginalized as "queer," that is, as those living outside of the homonormative lifestyles supported by legislative and social change (Binnie 2004; Ghaziani 2011; see also Duggan 2003; Richardson 2005).

The literature also suggests that gay villages are in decline because of increased internet and social media use (Miles 2021), allowing LGBT and queer individuals to find other like-minded individuals without the need for expressly LGBT and queer spaces such as gay villages (Miles 2021; Mowlabocus 2010; Nash and GormanMurray 2019a; Usher and Morrison 2010). Some LGBT and queer people, particularly youth, perceive the gay village as reflective of older generations' histories, sensibilities, and lifestyles (Nash 2013a; Sullivan 2005). These locations are arguably of little interest to newer generations, who are able to experience a wider variety of locations, identities, and subjectivities, and who are less interested, perhaps, in subscribing to essentialized gay and lesbian identities associated with gay villages. 
Both Toronto and Sydney include well-established gay villages, which over the last thirty years have been fully integrated into the fabric of each city's downtown core. Toronto's gay village emerged in the late 1970s and is presently centered on the intersection of Church and Wellesley Streets, one block east of Yonge Street (Fig. 11.1), Toronto's main downtown thoroughfare (Kinsman 1996; Warner 2002; Nash 2006). Today, the village remains the hub of gay social, economic, and political life with its collection of iconic bars (Fig. 11.2), restaurants, bathhouses, convenience

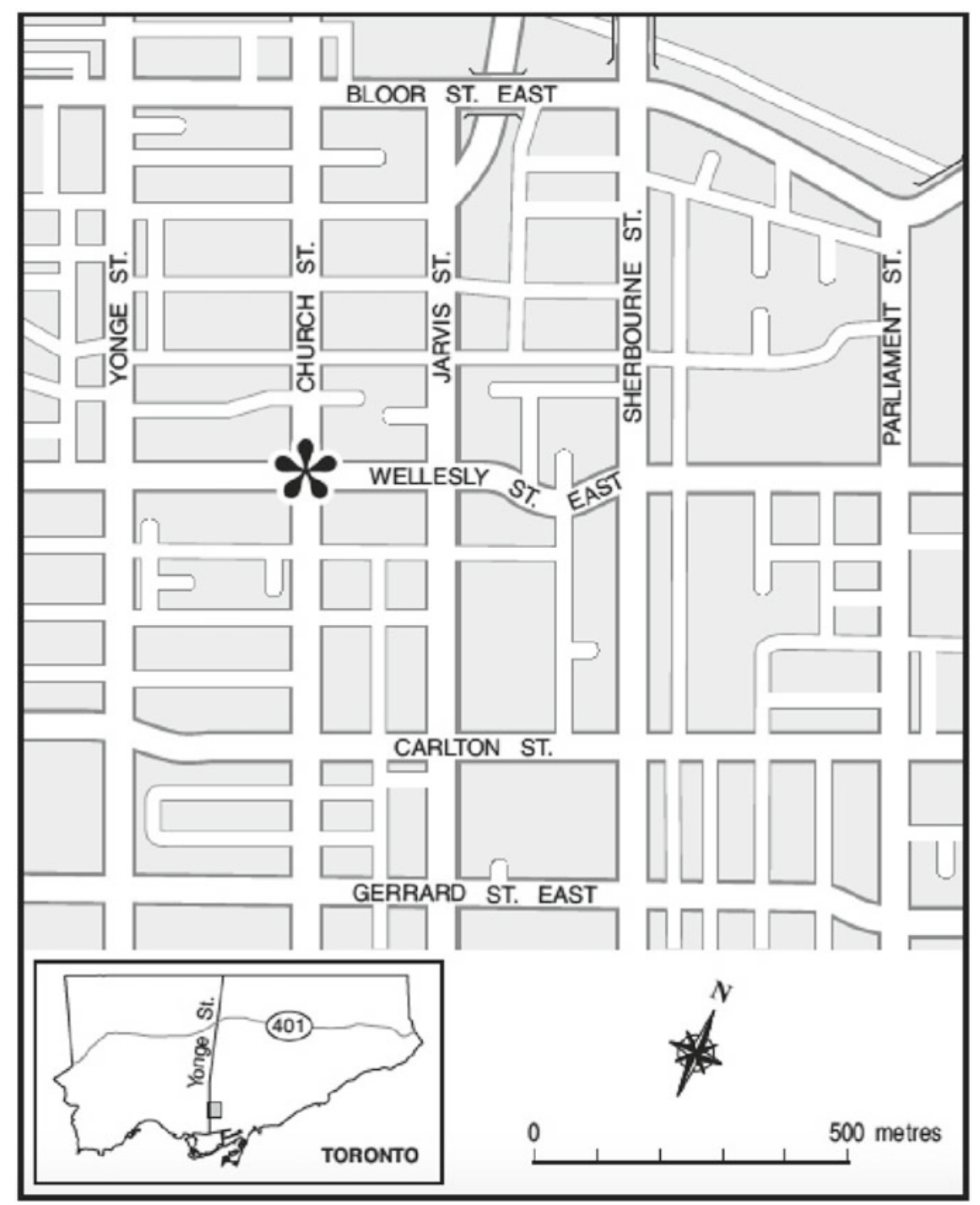

Fig. 11.1 Map of Church-Wellesley Village, Toronto (Source Map by Authors) 


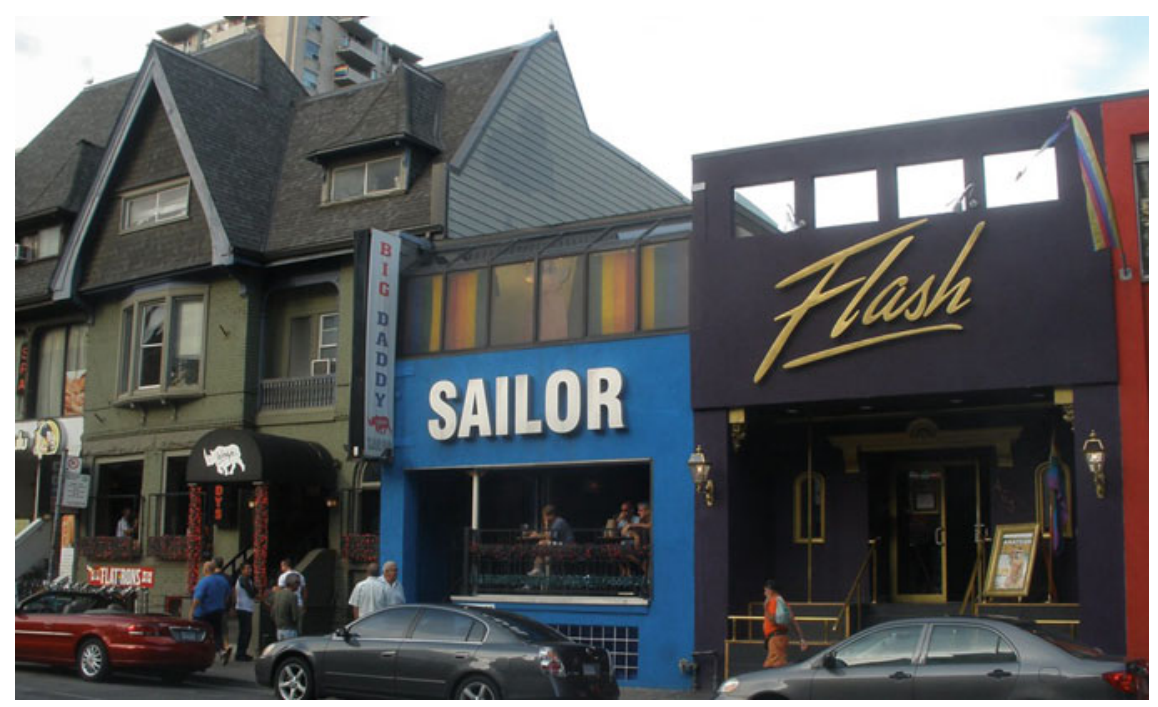

Fig. 11.2 Church Street, Toronto (Source "Toronto Church St" by ed and eddie is licensed under CC BY-SA 2.0)

stores, restaurants, and boutique shops, serving a substantial LGBT population in the surrounding residential neighborhood (Fig. 11.3). Sydney's gay village, popularly called Oxford Street, is adjacent to the Central Business District (CBD) in the inner east (Fig. 11.4). Nightlife, leisure, and commercial activities are focused along Oxford Street between College Street and Taylor Square (presently), comprising bars, clubs, cafes, sex shops, and other retailers, while there is a congregation of LGBT venues, community facilities (social and health services), and residents in the surrounding suburbs of Darlinghurst, Surry Hills, Paddington, and Potts Point.

At the present time, both Oxford Street and the Church and Wellesley villages are undergoing some form of metamorphosis. In both cities there is considerable debate over the exact nature and underlying causes of these changes, whether they can be understood as positive or negative, and whether LGBT and queer political organizations should be actively engaged in guiding or directing these transformations. Given that both villages and related events, such as Pride and Mardi Gras, are used to demonstrate their city's cosmopolitanism and competitiveness, mainstream interests, including local municipal councils and LGBT organizations, are concerned about the potential fate of their gay neighborhoods. To understand the nature and framing of these debates, we argue that it is important to understand each of these village's historical geographies.

Historical geographies offer insights into current processes, providing insights into the "how" and the "why" of current developments. Referring to the development of gay commercial districts, Camilla Bassi (2006: 215) argues, "each locale possesses its own peculiar historical and social processes, the outcome of which is by no means 


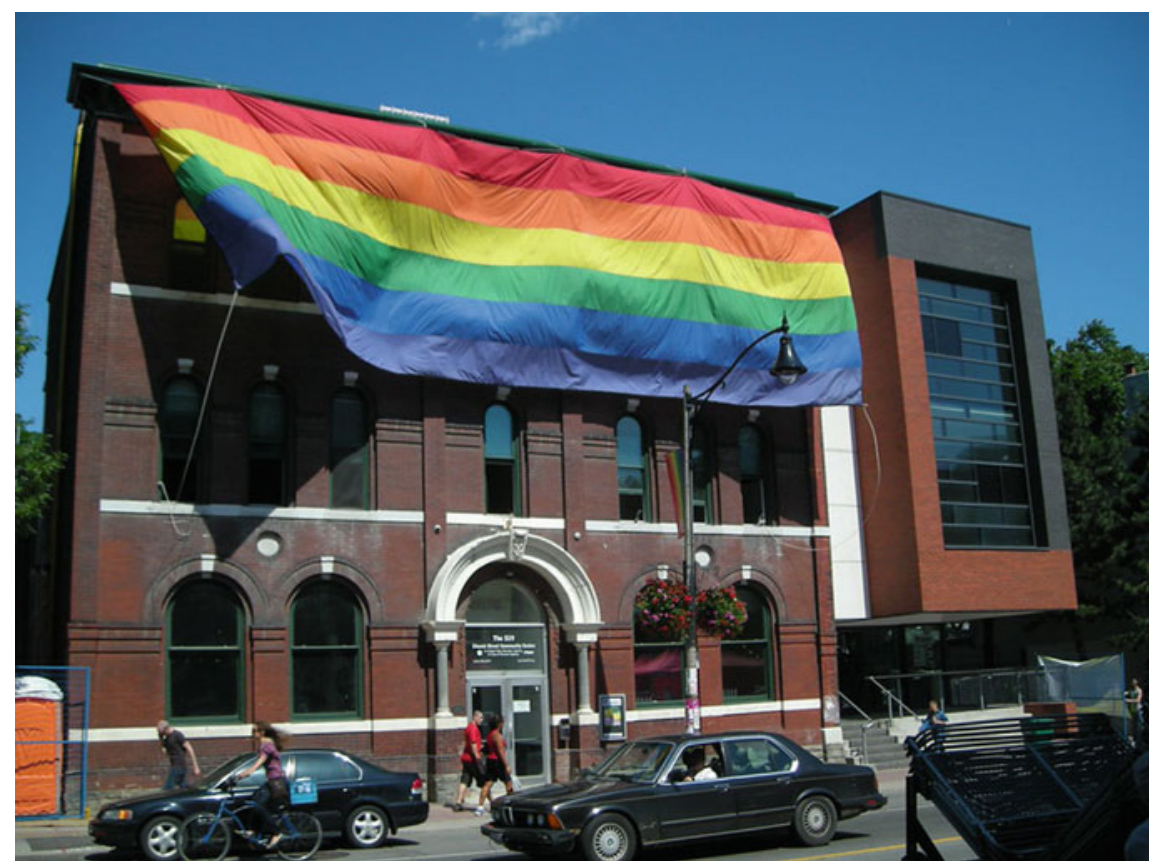

Fig. 11.3 519 Church Street Community Centre, Toronto (Source 519 Church Street Community Centre Toronto by Neal Jennings is licensed under CC BY-SA 2.0)

certain." Both Toronto and Sydney are world cities and major gateways for immigration and settlement (Bunting and Filion 2000; Desfor et al. 2006; Filion 1996; Sewell 1993). While it is beyond the scope of this chapter to lay out in detail the similarities between Toronto's and Sydney's gay village development, we would argue that our own work documents the notably similar political, economic, and social histories of the ongoing development of gay villages in Toronto and Sydney (Gorman-Murray and Nash 2014, 2017; Nash and Gorman-Murray 2014; Nash 2006, 2013a). LGBT and queer political and social activism within discrete national contexts has been markedly similar but with varying and distinctive differences (Tremblay, Paternotte and Johnson 2011).

In the following sections, we consider their respective historical geographies through three specific themes-post World War II planning policies, the emergence of "city of neighborhoods" discourses, and the positioning of gay villages within neoliberal processes of commodification and consumerism. 

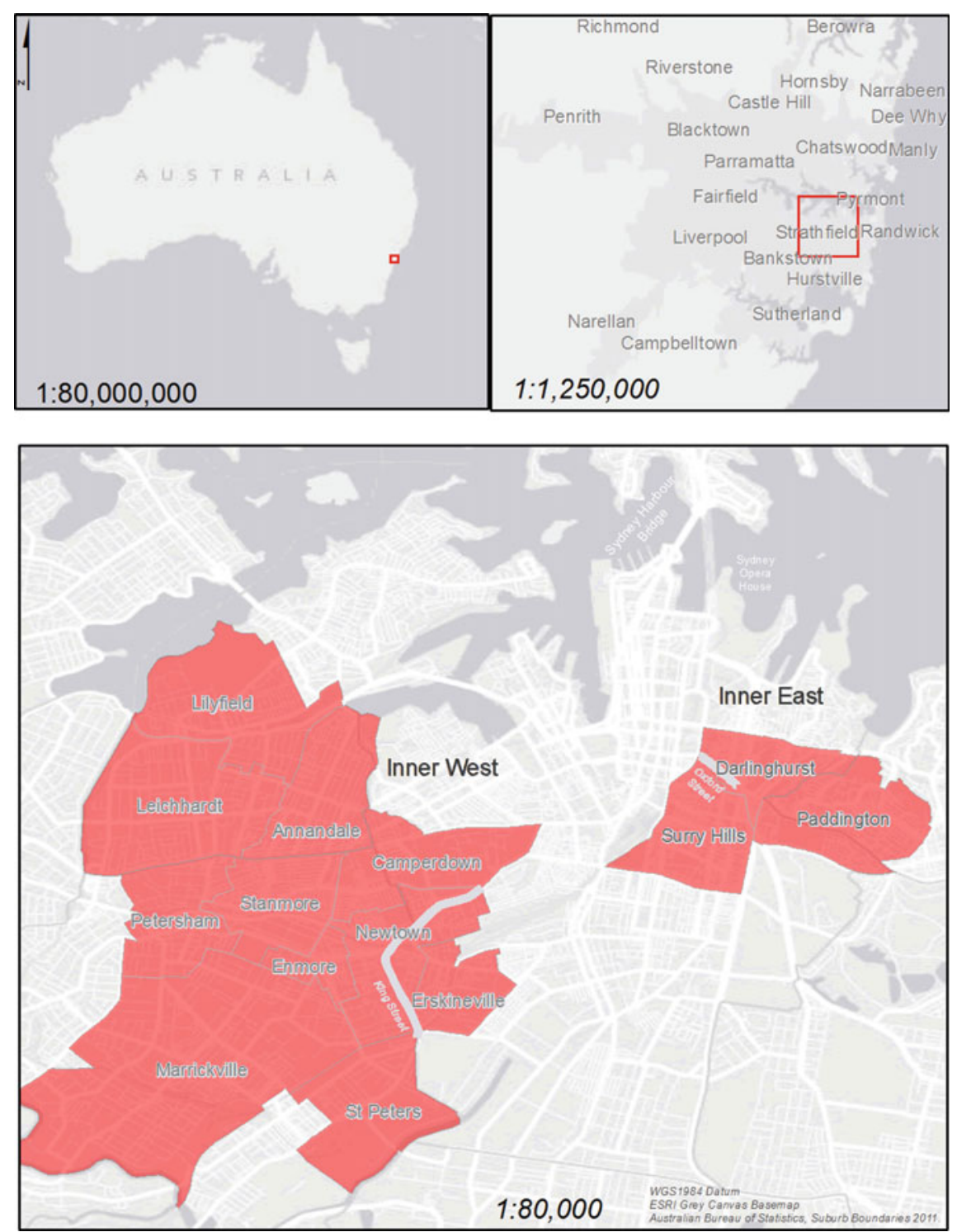

Fig. 11.4 Map of Sydney's LGBT neighborhoods: the Inner East, centred on Oxford Street, Darlinghurst, and the Inner West, centred on King Street, Newtown (Source Maps by Authors) 


\subsection{Historical Geographies of Sexuality in Toronto}

This section examines the intertwined histories of Toronto's shifting urban planning policies and the changing fortunes of what has become Toronto's "traditional" gay village. As one of Canada's major cities, Toronto's population increased substantially in the late 1930s as the country geared up for war, and then again during the war efforts in the 1940s (Sewell 1993). Toronto's downtown core, centered around Yonge Street from south of Bloor Street to Front Street, gained considerable notoriety, dotted with massage parlors, strip joints, discount stores, and an assortment of bars and restaurants, populated with those considered to have unsavory reputations and appetites. In keeping with the histories of other North American LGBT neighborhoods, Toronto's post-war homosexual population clustered in and around these less desirable areas, able to live relatively open lives among other marginalized groups in the Bloor and Church Street district (Egan 1998).

In the post-World War II period, City of Toronto planning policies were directed largely toward the inner suburbs surrounding the city of Toronto. Such efforts were driven by a deep desire to return to pre-war norms about the heterosexual family and children. Developers and planners stressed the notion that raising a family required single family homeownership, with greater indoor and outdoor space (Bunting, Filion and Walker 2010; Hernandez, Robinson and Larson 2010). Governments directly intervened to encourage such developments through the provision of subsidized schools, hospitals, housing, and the construction of roads and major arterial highways (Bunting, Filion and Walker 2010).

In Toronto, the boom in the suburban developments undermined inner-city neighborhoods as the middle and upper classes moved to the suburbs, encouraging the construction of major roadways through older downtown neighborhoods. Inner-city housing stock declined as larger homes were converted to multiple-unit rentals, alongside its physical deterioration, which supported planning initiatives for urban renewal and the demolition of older housing stock for public housing (Miron 1993). Toronto's gays and lesbians were unlikely to live in the newly developing suburbs, thereby encouraging many to live and work in the downtown core where their proclivities were more likely to be tolerated. Canadian cities (including Toronto) also experienced substantial immigration in the 1950s and 1960s, which supported the refurbishment of inner-city housing stock as ethnic minorities began to concentrate in recognizable districts or territories.

By the early 1970s, Toronto experienced local social movements pushing back against the state and promoting vibrant low-rise, eclectic inner-city neighborhoods (Searle and Filion 2010; Sewell 1993; Walks 2008). As the city embraced these ideas, the downtown experienced "a wave of heritage protection and the beginnings of inner-city gentrification in the early 1970s" (Lynch and Ley 2010: 330). Neighborhood preservationist movements were particularly successful in pushing back against development, prompting a shift in Canadian planning perspectives to one that increasingly regarded the downtown core as an important hub for regional 
economic health, the provision of goods and services, and a center for social and cultural life (Hernandez, Robinson and Larson 2010).

\subsubsection{A Nascent Gay Village: Toronto in the 1970s}

The partial decriminalization of homosexuality in 1969 opened up possibilities for more public activism. LGBT political and social organizations were founded in downtown Toronto in the early 1970s. The Community Homophile Association of Toronto (CHAT) established a community center, cafe, and library in the Church Street area. CHAT believed such spaces would bring together and politicize local gays and lesbians by providing alternative spaces alongside the bars and bathhouses (Nash 2006). Clashes with anti-gay activists, including Anita Bryant and local pastor Ken Campbell, as well as organizing against police harassment of bathhouses, fostered further political activism geared toward defending homosexual commercial establishments. By the end of the 1970s, gay and lesbian activists fully recognized the Church and Wellesley Street area as a gay neighborhood and called for its defense, not only by gays and lesbians but also by the local municipal council. In 1980, George Hislop ran as the first openly gay candidate for City Council.

In the background, the election of a City of Toronto "reform" council in 1969 prompted calls to end major urban renewal projects and to protect and preserve innercity neighborhoods. As a result of postmodern strategies of place-making (Lynch and Ley 2010: 311), ethnocultural neighborhoods were no longer perceived as temporary locations from which to aspire to assimilation but as stable and supportive communities contributing to the vibrancy of city life. Taken together, the new urban social movements, the development of stable ethnic enclaves, and the growing gay and lesbian rights movement encouraged an understanding of the Church and Wellesley Street neighborhood as one worth protecting as a legitimate political and social territory for gays and lesbians to participate in city life (Nash 2006).

Simultaneously, a wider shift in perceptions about urban life saw growing numbers of single women, single men, and childless couples enjoyed downtown residential lifestyles, fueling incipient gentrification (Bitterman 2021). Scholars have documented the important role that gay men and lesbians played as early gentrifiers in marginal locations in Toronto, including the impact of gay men in the Cabbagetown neighborhood adjacent to the nascent gay village in the early 1970s (Bouthillette 1994).

\subsubsection{Neoliberalism and Toronto's Gay Village}

In the 1990s, Canadian cities, including Toronto, experienced increasing financial strain as the Ontario provincial and federal governments began shifting the costs of welfare and social programs, and infrastructure repair and management, to local 
municipalities. In response, cities increasingly employed more entrepreneurial, selfpromotional approaches to attract new economic development. Neoliberal ideologies underpinned cities' endeavors to market themselves through the creation of place identities, edgy architecture, urban design, and cultural spectacle (Lynch and Ley 2010). City authorities understood the importance of "place-making" in creating a positive city image, making them magnets for employment, industry, and tourism.

By the early 2000s, Toronto's gay village (as with other gay villages in North America, Europe and Australia) was fully incorporated into the fabric of the postindustrial entrepreneurial city that knitted together commodified, consumer-based neighborhoods with downtown urban lifestyles (Binnie and Skeggs 2004; Nash $2013 \mathrm{a}, \mathrm{b})$. In a manner similar to other locations in the Global North, the gay village's incorporation into commodified urban landscapes is a reflection in part of the aspirations of some gay men and lesbians for inclusion in a neoliberal politics that results in the privileging of some gay men and lesbians who desire to live within middle class, gender-normative, monogamous coupledom - a form of homonormalization (Duggan 2003).

\subsubsection{Toronto's Village Today}

Today, Toronto's village is unequivocally included as one of the distinctive inner-city neighborhoods in the city's marketing and tourism activities. But recently, anxiety about its possible decline has grown, particularly with the loss of several iconic businesses, rising rents, and an influx of heterosexuals into the condominium market and entertainment venues. There are also claims that younger queers view the gay village as a relic of the past or a location that was never particularly welcoming of certain groups (Nash 2013b). Simultaneously, legislative and social advances, including human rights protections and same-sex marriage, mean that LGBT people are increasingly visible across a variety of locations. Other Torontonian neighborhoods supporting queer communities include Parkdale (“Queer West”), Brockton Village, Roncesvalles, and Leslieville. Our research suggests that rather than understanding changing gendered and sexual landscapes as manifestations of decline, it is more suitable to understand them as shifting relational geographies between neighborhoods, manifesting broader queer visibility and greater social cohesion (Nash and Gorman-Murray 2014).

Recently, the village has been presented with an opportunity for self-reflection in the wake of Toronto's successful bids for World Pride, held Spring 2014, and the Pan-American Games, held Summer 2015. Preparing for these events provided the local LGBT business community with an opportunity to undertake more long-range planning around the future of the gay village and its role in LGBT and queer life.

The Church and Wellesley Village Business Improvement Association (BIA) was created in 2002. BIAs pool funds from local businesses to undertake projects designed to "improve, beautify and maintain public lands in the BIA and promote the area for business and shopping" (Government of Ontario 2001: 204). The BIA formed a close 
association with the LGBT community, and following the successful World Pride and PanAm bids, the BIA and LGBT activists, with the support of Councilor Kristyn Wong-Tam, launched a planning study to determine the future direction of the gay village. Partly as a result of the planning study, the BIA undertook several initiatives to preserve the long-term economic viability of the village as a tourist attraction, including renovating Cawartha Park, commissioning a mural representing LGBT life, and opening "temporary parklets" along Church Street (Nash and Gorman-Murray 2019b).

Although the process is ongoing, it is possible to see the institution of particular narratives about the centrality and importance of the village for LGBT and queer people. This means, in part, a re-visioning of the village as a "place of arrival and return," as a place for people to come out, and as a place for LGBT and queer people to gather for political and social protest.

\subsection{Historical Geographies of Sexuality in Sydney}

We now discuss historical geographies of sexuality in Sydney, with attention to the emergence, development, and decline of the gay village around Oxford Street. This discussion picks up the three foundational themes-planning, neighborhood, and neoliberalism - and elicits Sydney's similarities and differences in comparison with Toronto, suggesting how and why these villages are developing in distinctive ways. Sydney is the oldest city in modern Australia, founded in 1788 when the colony (later state) of New South Wales (NSW) was established, and is Australia's primary global city. The immediate post-World War II era was a period of sustained population and economic growth. As part of the post-war rebuilding, federal and state governments' plans for economic and social development relied on policies encouraging population growth through natural increase and state-sponsored immigration. These policies were implicitly heteronormative, encouraging sexual and social reproduction through nuclear family units, realized in a "baby boom."

Such heteronormative policy was explicit in urban planning processes and practices in Sydney (Gorman-Murray 2011; Prior 2008). Increased population meant a need for increased housing, and state and private housing organizations, financial institutions, and land developers geared new suburban estates and "home packages" toward heterosexual nuclear families (Game and Pringle 1979; Johnson 2000). While the expanding Sydney suburbs were planned as sites of heteronormative family life, the inner city was seen as undesirable for residential development and more suited to industrial and commercial activities. In contrast with "familial" suburbia, nighttime inner-city Sydney was imagined as a site of vice and immorality, best seen in the clubs, prostitution, and crime associated with the red-light district in the inner east suburb of King's Cross (Johnson 2000; Dunn 2011).

It was in such liminal inner-city spaces that Sydney's gay and lesbian subcultures emerged, which historians suggest were more concentrated and visible than in other Australian cities (Wotherspoon 1991). However, the sites of that subculture-clubs, 
bars, cafes, baths - were transient, underground venues that shifted across Sydney's inner city, from the CBD to East Sydney, King's Cross, and Paddington, liable to social retribution and police raids (Wotherspoon 1991). However, the late 1960s brought public homosexual rights claims and murmurings of social acceptance in some liberal quarters, enabling enhanced visibility in the name of social and legal change (Willett 2000b). In the late 1960s a cluster of more visible gay clubs (e.g., Ivy's Birdcage, Capriccio's) settled on Oxford Street, and "from the early 1970s it was the Oxford Street area that became the focus for gay venues" (Wotherspoon 1991: 19). Amidst the mobile, relational geographies of the post-war period, the confluence of rights, politics, incremental social change, and an incipient geographical anchor provided the material foundation for a gay village in Sydney, centered on Oxford Street, eventually known by that same moniker (Fig. 11.5).

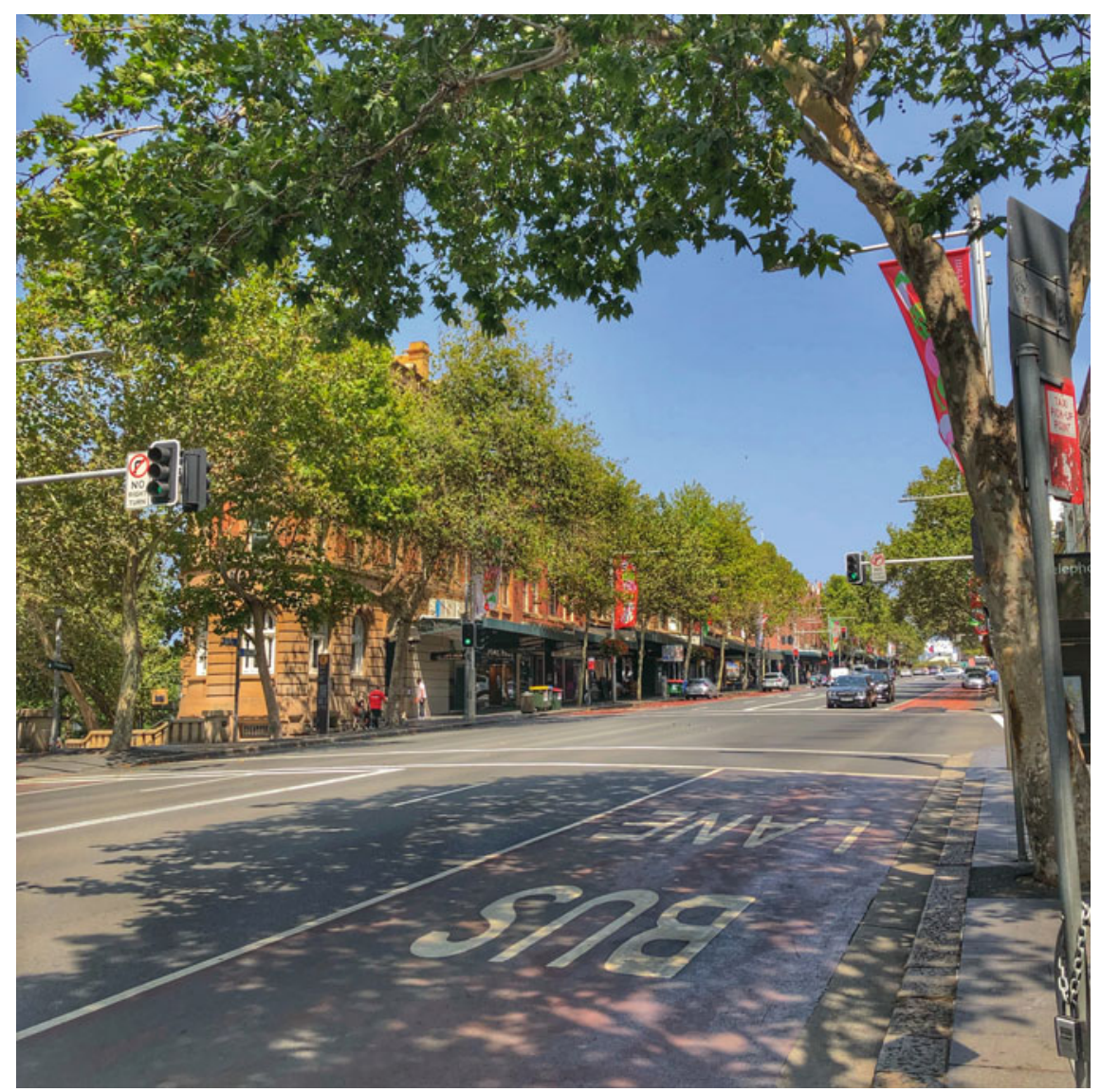

Fig. 11.5 Oxford Street, Darlinghurst, Sydney, 2019 (Source Image by Andrew Gorman-Murray) 


\subsubsection{Consolidation of a Gay Neighborhood: Sydney in the 1970s to the 1990s}

The consolidation of Oxford Street as a gay area occurred quickly, with fractions of the gay community inspired by gay neighborhoods emerging in San Francisco's Castro and Los Angeles's West Hollywood (Wotherspoon 1991). Building on the foundation of the successful late 1960s bars, there was a rapid emergence of venues around Oxford Street, which became a locus for clubs, bars, baths, sex-on-premises venues, and bookshops. The clustering generated a "gravitational effect," drawing a gay residential population to the surrounding suburbs Darlinghurst, Surry Hills, Paddington, and Potts Point (Fig. 11.4). Of course, gay men and lesbians had lived in the inner city earlier, given the relatively cheap cost of accommodation in these undesirable areas, but the late 1960s saw the beginning of inner-city housing gentrification. Within a short period, a discrete geographical area had emerged as a site of "gay identity" in both commercial and residential terms (Knopp 1998). As Wotherspoon (1991: 193) argues, "there was now a definite area where the new 'gay' man could feel at home, in territory that was clearly stamped in his image." The village consolidated further across the 1970s and 1980s. During these decades, gay press offices proliferated; gay rights groups relocated to the neighborhood; health services aimed at gay clientele moved in (GPs, dentists, counselors, and HIV/AIDS services); and services for gay youth (Twenty10) or religious gays (Metropolitan Community Church) were established (Ruting 2008).

Oxford Street's development has entailed successes and failures. One of the failings of its ad hoc consolidation was the attention of services to gay men and the displacement of lesbian services and residents. With gentrification, lesbians, often with less financial means than gay men, were priced out of the housing market, while services aimed at lesbians and other queer women were similarly affected by increasing commercial rents. This contributed to the development of a discrete lesbian residential and service neighborhood during the 1980s in the inner west suburb Leichhardt (Murphy and Watson 1997; Nash and Gorman-Murray 2015). Women's health services, lesbian counseling services, women's refuges, women's and lesbians' social and business clubs, and lesbian residents began to congregate in the suburb, earning it the moniker "Dykehardt." However, this was also a loss to Oxford Street and its local sexual and gender diversity, which remains largely associated with gay men.

The consolidation of Oxford Street as "gay territory" also yielded distinct benefits. The spatial concentration of gay commerce, organizations, and residents provided political strength for securing rights claims - a "concentrated voice" that impelled NSW anti-discrimination laws (1982) and the decriminalization of homosexuality (1984). Parallel with such changes in NSW parliament, a geographical hub for LGBT community organizations and leadership (and commercial and sex venues, and residents) allowed for a coordinated, joint response from the state and the gay community to HIV/AIDS in the early 1980s, generating one of the most effective responses globally, targeting safer sex messages at the gay community, keeping infection rates 
relatively low (c. 14/100,000 people cf. 167/100,000 in the United States) (Willett 2011). The local government (City of Sydney Council) and representatives for the NSW electorate have consistently championed LGBT causes.

The neighborhood has been an economic success too, highlighted by the Sydney Gay and Lesbian Mardi Gras Festival, a month-long LGBT festival incorporating a famous parade along Oxford Street, dance parties, a film festival, and cultural and sporting events. The parade has been held annually since 1978, initiated as a local response supporting Stonewall Day. Since then, the Mardi Gras Festival has become an international tourist event supported by the NSW government and the City of Sydney Council, earning up to A $\$ 90$ million per annum (Waitt and Markwell 2006).

\subsubsection{An End to Village Life in Sydney?}

Yet the early twenty-first century has witnessed stories of the Oxford Street's decline in the LGBT and mainstream press, the closure of iconic venues and the movement of many LGBT organizations elsewhere in the inner city, alongside the notable increase in "straight" nightclubs (Gorman-Murray 2006; Ruting 2008; Reynolds 2007, 2009). Researchers suggest several reasons for this decline as a gay locale, including increasing straight residents (and venues) due to the "cultural cache" of the gay village; rising rents pricing out gay residents and businesses; and online networks, reducing the need for a spatial concentration of social venues. The commercial strip has shifted toward a nightlife focus, with a preponderance of nightclubs and a diminishing number of cafes, restaurants, and retail outlets.

This decline has been challenged for diverse political and economic reasons. Middle-aged and older men, and generations of activists, remember Oxford Street as a site of political developments, coming out and social life, and seek to hold onto this well-known territory for themselves and future generations. The City of Sydney Council seeks to sustain the political and economic success of Oxford Street, incorporating it into its neoliberal "city-marketing" strategy — the "City of Villages"- as an internationally renowned "gay village." To this end, the City of Sydney Council has instituted a series of strategies and plans aimed at reducing the problems facing the gay village and recuperating its perceived gay character (Reynolds 2009). These include the establishment of "safe space" along the street and initiatives to re-occupy the street with "daytime" creative enterprises by offering low-rent or rent-free shop fronts to artists and pop-up stores. These neoliberal strategies attempt to rebuild a broader local commercial base, enticing citizen-consumers back.

The perceived decline in Oxford Street since the early 2000s has been matched by the development of another LGBT neighborhood in Sydney's inner west, centered on King Street, Newtown (Fig. 11.6), with a residential spread into the surrounding suburbs of Camperdown, Erskineville, Enmore, St. Peters, and Marrickville (Fig. 11.4), which has been proffered by the LGBT media and local residents as a new LGBT heartland of Sydney (Gorman-Murray 2006; GormanMurray and Waitt 2009). There are increasing LGBT and LGBT-friendly venues 


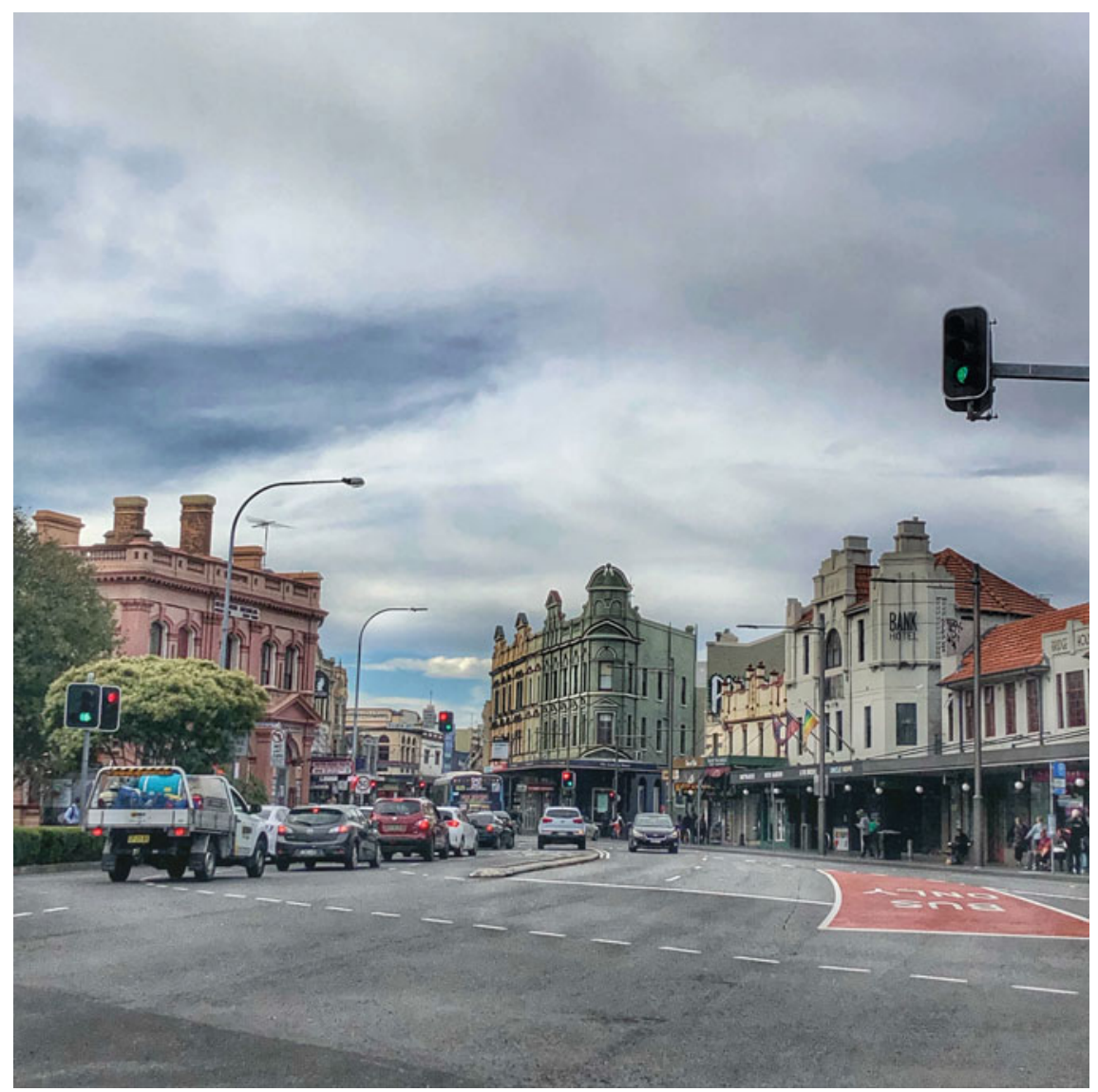

Fig. 11.6 King Street, Newtown, Sydney, 2020, with The Bank Hotel flying LGBT flags (right hand side of the street) (Source Image by Andrew Gorman-Murray)

(e.g., The Imperial, Newtown, and Bank Hotels), while several LGBT organizations have moved in (e.g., Twenty10, the Australian Federation of AIDS Organisations, a Metropolitan Community Church congregation, and the Gay and Lesbian Counselling Service). Significantly, there are venues and organizations that cater for the LBT in LGBT. The area is home to The Gender Centre, the key NSW advocacy service for trans and genderqueer rights. Much of Sydney's lesbian social scene can be found in local venues (e.g., The Imperial, Bank, and Sly Fox hotels).

While Oxford Street is typically understood as a gay male space, Newtown and the inner west are seen to provide a home for a broader sexual and gender demographic, including lesbians, queer women, and trans people. The Australian Census 2011 found that the ten suburbs with the highest concentration of male and female same-sex couples were in inner-city Sydney, but while male couples are most concentrated in Darlinghurst, Surry Hills, and Potts Point in the inner east, female couples 
are concentrated in Newtown, St. Peters, Enmore, Erskineville, and Marrickville in the inner west, alongside still significant concentrations of male couples. The combination of residential concentrations of female and male couples, as well as a congregation of LGBT commercial venues and organizational services since 2000, indicates the presence of a LGBT neighborhood in Sydney's inner west. While some suggest that this challenges the continuance of Oxford Street, others contend that the inner west caters to a different LGBT demographic - one perhaps more inclusive of sexual and gender diversity than the "traditional" gay (male) ghetto.

\subsection{Thoughts on Historical Legacies and the Future of the Gay Village}

We argue that the distinct historical geographies of the Church-Wellesley and Oxford Street gay villages help to position each differently within the urban fabric of, respectively, Toronto and Sydney. These different historical geographies and urban legacies enable (perhaps) divergent futures. Toronto's Church-Wellesley village now finds itself in a more hopeful set of circumstances in terms of determining its future vis-à-vis Sydney's Oxford Street. The use of the "ethnic" model of territorial identity in Church-Wellesley village arguably benefitted from an earlier recognition and incorporation of "other" ethnic differences in processes of political inclusion, cultural heritage, and urban planning than in Sydney. The village's location, initially marginal, benefitted from being close to Yonge Street when the city began rejecting urban renewal planning and instead embraced inner-city preservation.

The drive to preserve heritage, difference, and unique neighborhoods emerged much later in Sydney, not taking hold until the 1990s. Since then, in Sydney as well as Toronto, the local city councils have incorporated their "gay villages" into "city of neighborhoods" discourses, aimed at boosting initiatives around creative industries, marketing, and tourism by commodifying the diversity, cosmopolitanism, and lifestyle of the inner city. But there has been a difference here between Toronto and Sydney, arguably resulting from the earlier recognition of Church-Wellesley as a unique neighborhood. Even as the City of Sydney Council rolled out its "City of Villages" campaign in the early 2000s, Oxford Street was not identified as the only gay village in Sydney. Already by the early 2000s, the City of Sydney was identifying Newtown and Erskineville, which lie within its jurisdictional boundaries, as other gay spaces in the inner city alongside Oxford Street. Since that time, Oxford Street has continued to decline materially and imaginatively as the gay village within Sydney, while Newtown and the inner west have continued to solidify as queer neighborhoods (Gorman-Murray and Nash 2014, 2017; Gorman-Murray and Waitt 2009).

As a result of the different political and territorial legacies of Church-Wellesley and Oxford Street, it seems that late 2000s discourses about the deterioration of gay villages arguably promoted debates about the preservation and future of ChurchWellesley before it reached the state of decline being experienced by Oxford Street. 
Indeed, the village evinces a strong institutional base in the form of 519 Church, the BIA, and a lesbian-identified city councilor dedicated to the economic and social health of the area. These institutions are taking advantage of high-profile events such as World Pride and the PanAm Games for self-reflection and to "rebuild" the territory and identity of the village as central in the lives of new generations of LGBT and queer people. This is not to say that such attempts have not been made around Oxford Street. However, we have suggested, the particular historical geography of Oxford Street has yielded specific pressures and fewer opportunities to stabilize its territory and identity.

For instance, there are some quite geographical issues concerning the location and physical affordance of Oxford Street and its connection with Sydney's downtown core. The Church-Wellesley Village is located downtown, and has benefitted from being in Toronto's core, near the Eaton Centre, iconic Maple Leaf Gardens, refurbished Dundas Square, and Ryerson University, a location central to urban regeneration schemes. Oxford Street, however, is one suburb east of Sydney's CBD and separated by parkland, a seemingly minor difference but consequential for its integration in urban change. The significant regeneration of Sydney's CBD that has taken place since the 1980s has focused on the northern (Circular Quay, The Rocks) and western sides (Darling Harbour, Barangaroo) of the city core, with the east (Hyde Park, East Sydney, and Oxford Street) receiving less attention. Oxford Street itself is not a place for sightseeing and daytime leisure vis-à-vis refurbished Circular Quay, Darling Harbour, Barangaroo, and The Rocks.

The changes in Oxford Street's business profile, its disconnection from the CBD, and the movement of the city's core toward the west, while not "causing" the development of Newtown as a queer neighborhood, have arguably helped facilitate changing LGBT spaces and networks. In Toronto, however, given its specific historical geographies and affordances, the Church-Wellesley village seems to be regrouping and rebranding with some success, partly due to current opportunities with local businesses and politicians who are committed to the village and taking advantage of upcoming hallmark events. The Church-Wellesley village arrives at this point in time with similar pressures as Oxford Street in terms of rising rents, changing demographics, and the use of social media apps leading to a downturn in clientele (Miles 2021). Yet it is also quite differently incorporated into the urban fabric - both the downtown core and other neighborhoods-enabling opportunities to proactively write a narrative in response to changes and draw on resources to stabilize itself. While there are alternative neighborhoods emerging, such as Queer West and Leslieville, they are not materialized in the relational geographies of LGBT landscapes in the way Newtown has become embedded as a queer neighborhood in Sydney, with a distinct profile connected with but contesting Oxford Street. 


\subsection{Concluding Remarks: Wider Implications for Urban Planning and Policy}

What implications might these historical geographies have for urban planners and local governments? On the one hand, the mutable geographies of LGBT and queer spaces might prompt a call for "remembering" and "fixing" certain sites (venues, neighborhoods) "identified" as LGBT or queer. On the other hand, this same mutability should also alert planners and policy-makers to the reality that LGBT and queer lives and spaces cannot be readily "fixed" in place. Arguably, part of the geographical heritage of these communities is their mobility-even if this is, at the same time, the result of physical constraints on social marginality. This means that planners and policy-makers must be aware of at least two important realizations. First, LGBT and queer communities are diverse, not singular, encompassing differences of gender, ethnicity, generation, class, etc., all of which need to be attended to in planning and policy to meet the wide needs and aspirations of these communities. Second, it is not only "identified" LGBT and queer places that must accommodate sexual and gender diversity: all spaces need to be inclusive of LGBT and queer lives.

We see these two dimensions of planning — acknowledging specific geographical heritage and building broad spatial inclusion-as complementary. Remembering (possibly reclaiming) significant LGBT and queer urban spaces provides important moorings for these communities in the face of mutable geographies. But it is equally important to be cognizant of how urban spaces are constantly reconfigured and utilized in different ways in response to shifting gender and sexual subjectivities. This behooves planners and policy-makers to develop sensitivity to the changing spatial imperatives of LGBT and queer people, and to accommodate these mobile lives in planning to ensure the ongoing strength and sustainability of these communities.

Acknowledgment This chapter originated as an article in the open-access journal Historical Geography $(2015,43: 84-105)$, which has been substantially re-worked for publication in this edited volume. We thank Arn Keeling, the journal editor, for permission. We thank Emilie Baganz for editorial assistance.

\section{References}

Adler S, Brenner J (1992) Gender and space: lesbians and gay men in the city. Int J of Urban Reg Res 16(1):24-34

Bassi C (2006) Riding the dialectical waves of gay political economy: a story from Birmingham's commercial gay scene. Antipode 38:215-35

Bell D, Binnie J (2002) The sexual citizen: Queer politics and beyond. Polity, Cambridge

Binnie J (2000) Cosmopolitanism and the sexed city. In: Bell D, Haddour A (eds) City visions. Pearson Education, New York, pp 166-78

Binnie J (2004) The globalization of sexuality. Sage, London

Binnie J, Skeggs B (2004) Cosmopolitan knowledge and the production and consumption of sexualized space: Manchester's gay village. Sociol Rev 52(1):39-61 
Bitterman A (2021) The rainbow connection: a time-series study of rainbow flag display across nine Toronto neighborhoods. In: Bitterman A, Hess DB (eds) The life and afterlife of gay neighborhoods: renaissance and resurgence. Springer, Dordrecht, Netherlands, pp 117-140

Bouthillette AM (1994) Gentrification by gay male communities: A case study of Toronto's Cabbagetown. In: Whittle S (ed) The margins of the city: gay men's urban lives. Ashgate, Aldershot, pp 65-84

Brown G (2008) Urban (homo) sexualities: Ordinary cities and ordinary sexualities. Geogr Comp 2(4):1215-1231

Brown G (2009) Thinking beyond homonormativity: performative explorations of diverse gay economies. Environ Plan A 41(6):1496-1510

Bunting T, Filion P (eds) (2000) Canadian cities in transition: the twenty-first century. Oxford University Press, Don Mills, Ontario

Bunting T, Filion P, Walker R (eds) (2010) Canadian cities in transition: new directions in the twenty-first century. Oxford University Press, Toronto

Castells M (1983) The city and the grassroots: a cross-cultural theory of urban social movements. University of California Press, Berkeley and Los Angeles

Chauncey G (1994) Gay New York: Gender, urban culture, and the making of the gay male world, 1890-1940. Basic Books, New York

Collins A (2004) Sexual dissidence, enterprise and assimilation: bedfellows in urban regeneration. Urban Stud 41:1789-1806

Desfor G, Keil R, Kipfer S, Wekerle G (2006) From surf to turf: No limits to growth in Toronto. Stud Polit Econom 77:131-155

Doan P, Higgins H (2011) The demise of queer space? resurgent gentrification and the assimilation of LGBT neighborhoods. J Plan Educ Res 31:6-25

Duggan L (2003) The twilight of equality? neoliberalism, cultural politics and the attack on democracy. Beacon Press, Boston

Dunn M (2011) Kings Cross. Dictionary of Sydney. https://dictionaryofsydney.org/entry/kings_ cross. Accessed 27 Nov 2019

Egan J (1998) Challenging the conspiracy of silence: my life as a gay Canadian activist. Canadian Lesbian and Gay Archives, Toronto

Filion P (1996) Metropolitan planning objectives and implementation constraints: planning in a post-Fordist and postmodern age. Environ Plan A 28:1637-1660

Game A, Pringle R (1979) Sexuality and the suburban dream. Aus NZ J Sociol 15:4-15

Ghaziani A (2011) Post-gay collective identity construction. Soc Probl 58:99-125

Ghaziani A (2021) Why gayborhoods matter: the street empirics of urban sexualities. In: Bitterman A, Hess DB (eds) The life and afterlife of gay neighborhoods: renaissance and resurgence. Springer, Dordrecht, Netherlands, pp 87-114

Gorman-Murray A (2006) Imagining King Street in the lesbian and gay media. M/C J 9, http://jou rnal.media-culture.org.au/0607/04-gorman-murray.php. Accessed 27 Nov 2019

Gorman-Murray A (2011) Queerying planning in Australia: the problems and possibilities of multiscalar governance for LGBT sexual minorities. In: Doan P (ed) Queerying planning: challenging heteronormative assumptions and reframing planning practice. Ashgate, Farnham, pp 129-143

Gorman-Murray A, Nash CJ (2014) Mobile places, relational spaces: conceptualizing an historical geography of Sydney's LGBTQ neighbourhoods. Environ Plan D Soc Space 32(4):622-641

Gorman-Murray A, Nash CJ (2017) Transformations in LGBT consumer landscapes and leisure spaces in the neoliberal city. Urban Stud 54(3):786-805

Gorman-Murray A, Waitt GR (2009) Queer-friendly neighbourhoods: Interrogating social cohesion across sexual difference in two Australia neighbourhoods. Environ Plan A 41(12):2855-2873

Government of Ontario (2001) Municipal Act 2001. Ontario. https://www.ontario.ca/laws/statute/ $01 \mathrm{~m} 25$. Accessed 8 November 2019

Hernandez T, Robinson J, Larson P (2010) Transforming downtown Yonge: implemented strategy through measured actions. J Town City Managem 1(1):47-57 
Johnson L (2000) Placebound: Australian feminist geographies. Oxford University Press, South Melbourne

Kinsman G (1996) The regulation of desire: homo and hetero sexualities. Black Rose Books, Montreal

Knopp L (1990) Some theoretical implications of gay involvement in an urban land market. Politic Geogr 9(4):337-352

Knopp L (1998) Sexuality and urban space: gay male identity politics in the United States, the United Kingdom and Australia. In: Fincher R, Jacobs JM (eds) Cities of difference. Guilford Press, New York, pp 149-178

Lewis N (2012) Remapping disclosure: gay men's segmented journeys of moving out and coming out. Soc Cult Geogr 13(3):211-231

Lynch N, Ley D (2010) The changing meanings of urban places. In: Bunting T, Filion P, Walker R (eds) Canadian cities in transition. Oxford University Press, Toronto, pp 325-341

Miles S (2021) Let's (not) go outside: Grindr, hybrid space, and digital queer neighborhoods. In: Bitterman A, Hess DB (eds) The life and afterlife of gay neighborhoods, pp 205-222

Miron JR (ed) (1993) Demographic and economic factors in housing demand. In: House, home and community: Progress in housing Canadians, 1945-1986. Mortgage and Housing Corporation, Toronto

Mowlabocus S (2010) Gaydar culture: gay men, technology and embodiment in the digital age. Ashgate, Surrey

Murphy P, Watson S (1997) Surface city: Sydney at the millennium. Pluto Press, Annandale

Nash CJ (2006) Toronto's gay village (1969-1982): plotting the politics of gay identity. Can Geogr $50(1): 1-16$

Nash CJ (2013a) Queering neighbourhoods: politics and practice in Toronto. ACME: I E-J Critic Geogr 12(2):193-219

Nash CJ (2013b) The age of the 'post-mo'? Toronto's gay village and a new generation. Geoforum 49:243-254

Nash CJ, Gorman-Murray A (2014) LGBT neighbourhoods and 'new mobilities': towards understanding transformations in sexual and gendered urban landscapes. Int J Urban Reg Res 38(3):756-772

Nash CJ, Gorman-Murray A (2015) Lesbians in the city: mobilities and relational geographies. J Lesbian Stud 19(2):173-191

Nash CJ, Gorman-Murray A (2019a) The geographies of digital sexuality. Palgrave, Melbourne

Nash CJ, Gorman-Murray A (2019b) LGBT place management: representative politics and Toronto's gay village. In: Tremblay M (ed) LGBT people and electoral politics in Canada. UBC Press, Vancouver, pp 298-313

Nast H (2002) Queer patriarchies, queer racisms, international. Antipode 34(5):874-909

Podmore JA (2001) Lesbians in the crowd: gender, sexuality and visibility along Montréal's Boul. St-Laurent. Gend Place Cult 8(4):333-355

Podmore JA (2013) Lesbians as village 'queers': the transformation of Montréal's lesbian nightlife in the 1990s. ACME: I E-J Critic Geogr 12(2):220-249

Prior J (2008) Planning for sex in the city: urban governance, planning and the placement of sex industry premises in inner Sydney. Aust Geogr 39:339-352

Reynolds R (2007) What happened to gay life? University of New South Wales Press, Sydney

Reynolds R (2009) Endangered territory, endangered identity: Oxford Street and the dissipation of gay life. J Aust Stud 33:79-92

Richardson D (2005) Desiring sameness? The rise of a neoliberal politics of normalisation. Antipode 37(3):515-535

Rothenberg T (1995) 'And she told two friends' lesbians creating urban social space. In: Bell D, Valentine G (eds) Mapping desire: Geographies of sexualities. Routledge, London, pp 150-165

Ruting B (2008) Economic transformations of gay urban spaces: Revisiting Collins' evolutionary gay district model. Aust Geogr 39:259-269 
Searle G, Filion P (2010) Planning context and urban intensification outcomes: Sydney versus Toronto. Urban Stud: 1-20

Sewell J (1993) The shape of the city: Toronto struggles with modern planning. Praeger, New York Sullivan A (2005) The end of gay culture: Assimilation and its meanings. The New Republic, Oct. 24:16-19

Tremblay M, Paternotte D, Johnson C (eds) (2011) The lesbian and gay movement and the state: Comparative insights into a transformed relationship. Ashgate, Farnham

Usher N, Morrison E (2010) The demise of the gay enclave: communication infrastructure theory and the transformation of gay public space. In: Pullen C, Cooper M (eds) LGBT identity and online new media. Routledge, London, New York, pp 271-287

Valentine G (1993) (Hetero)sexing space: Lesbian perceptions and experiences of everyday spaces. Environ Plan D Soc Space 11:395-413

Valentine G (1996) Lesbian productions of space. In: Duncan N (ed) Bodyspace: Destabilising geographies of gender and sexuality. Routledge, New York, pp 145-155

Visser G (2008) The homonormalisation of white heterosexual leisure spaces in Bloemfontein. South Africa. Geoforum 39(3):1347-1361

Visser G (2013) Challenging the gay ghetto in South Africa: Time to move on? Geoforum 49:268274

Waitt G, Markwell K (2006) Gay tourism: culture and context. Haworth Press, New York

Walks AR (2008) Urban form, everyday life, and ideology: support for privatization in three Toronto neighbourhoods. Environ Plan A 40(2):258-282

Warner T (2002) Never going back: a history of queer activism in Canada. University of Toronto Press, Toronto

Willett G (2000a) Living out loud: a history of gay and lesbian activism in Australia. Allen \& Unwin, St Leonards

Willett G (2000b) Australian gay activists: from movement to community. Radic Hist Rev 76:169_ 187

Willett G (2011) (updated) Australia. In: GLBTQ: An encyclopedia of gay, lesbian, bisexual, transgender and queer culture. GLBTQ Books, Chicago

Wotherspoon G (1991) City of the plain: history of a gay sub-culture. Hale and Iremonger, Sydney

Andrew Gorman-Murray is a Professor of Geography in the School of Social Sciences at Western Sydney University, Australia. Gender, sexuality and space is one of his critical research interests, and he has examined this in relation to urban and regional geographies, household dynamics, mobilities, wellbeing and disaster planning. He is currently working with Catherine Jean Nash on LGBT+ mobilities, digital life and neighbourhood transformations in Sydney, Australia and Toronto, Canada, and with David Bissell and Libby Straughan on the impact of mobile work on households, individuals and wellbeing in Australia. His books include Material Geographies of Household Sustainability (with Ruth Lane, 2011), Sexuality, Rurality and Geography (with Barbara Pini and Lia Bryant, 2013),Masculinities and Place (with Peter Hopkins, 2014), Queering the Interior (with Matt Cook, 2018) and The Geographies of Digital Sexuality (with Catherine Jean Nash, 2019).

Catherine Jean Nash is a Professor of Geography in the Department of Geography and Tourism Studies at Brock University, Canada. Her research interests include geographies of sexualities, queer, feminist and trans geographies, mobilities and digital sexualities. She is currently working with Kath Browne (and Andrew Gorman-Murray) tracing transnational oppositions to LGBT+ rights in Canada, the UK and Ireland, and with Andrew Gorman-Murray on new mobilities, digital life and transformations in LGBT+ and queer neighbourhoods in Sydney, Australia and Toronto, Canada. Her books include Queer Methods and Methodologies (with Kath Browne, 2016), The Geographies of Digital Sexuality (with Andrew Gorman-Murray, 2019), and the Canadian edition of Human Geography: People, Place and Culture (with Erin Fouberg et al. 2015). 
Open Access This chapter is licensed under the terms of the Creative Commons Attribution 4.0 International License (http://creativecommons.org/licenses/by/4.0/), which permits use, sharing, adaptation, distribution and reproduction in any medium or format, as long as you give appropriate credit to the original author(s) and the source, provide a link to the Creative Commons license and indicate if changes were made.

The images or other third party material in this chapter are included in the chapter's Creative Commons license, unless indicated otherwise in a credit line to the material. If material is not included in the chapter's Creative Commons license and your intended use is not permitted by statutory regulation or exceeds the permitted use, you will need to obtain permission directly from the copyright holder.

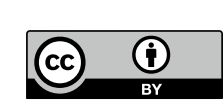

